\title{
HCD法によるTiNコーティング鋼の耐食性
}

\author{
黒河圭子*，小平隆志*，中山佳則 ${ }^{* *}$, \\ 滝沢貴久男 ${ }^{* *}$, 今井八郎 ${ }^{* * *}$
}

\section{Corrosion Resistance of TiN-Coating Steels Prepared by the HCD Process}

Keiko KUROKAWA* , Takashi ODAIRA* , Yoshinori NAKAYAMA**, Kikuo TAKIZAWA** and Hachiro IMAI***

Key Words : Corrosion, Ion Plating, HCD Process, Titanium Nitride, Stainless Steel

\section{1. 緒言}

イオンプレーティング（以下IP）を用いたTiN皮膜 生成, 並びに得られた皮膜の性質に関しては, 多くの報

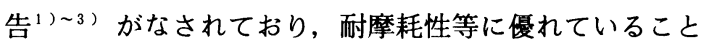
が知られている。しかし，湿式環境下での耐食性に関す る報告例は少ない。

本研究ではHCD (Hollow Cathode Discharge) 式の工業炉 ${ }^{4)}$ に, 種々の条件でステンレス鋼上にTiN 皮膜を形成し, 主に電気化学的方法によって耐食性の評 価を行い, 同時にTiアンダーコートや積層の効果, 皮 膜形成温度が与える影響についても検討した。

\section{2. 実験方法}

試料は，母材にSUS 304鋼を用い，表面を\#1000ま で湿式研磨した後ダイヤモンドペースト仕上げし， HC D式の工業炉にて，以下に示す条件でIP処理を施した。 No.1; TiNのみ $450^{\circ} \mathrm{C}, \quad$ No.2 ; Ti-TiN $450^{\circ} \mathrm{C}$, No.3 ; TiTiC-TiN $450^{\circ} \mathrm{C}$, No.4 ; Ti-TiC-TiN $300^{\circ} \mathrm{C}$, No.5 ; Non coating（末処理）

耐孔食性および耐すきま腐食性は, それぞれ塩化物水 溶液中でのアノード分極曲線, 自然電位 $\left(E_{\text {corr }}\right)$ の経時 変化, すきま腐食再不動態化電位 $\left(E_{\mathrm{R}}\right)$, 自然浸せきに よる重量減少量などの測定を行うことにより評価した。 また皮膜解析や腐食形態の観察には, SEM, EPMA, X線回折装置を用いた。

*三洋電機(㑣)空調研究センター（テ370-05 群馬県邑楽郡大 泉町坂田180)

Air-Conditioning R\&D Center, Sanyo Electric Co. ,Ltd. (180, Sakata, Oizumi-machi, Ora-gun, Gunma 370-05)

**三洋電機烌（干369-01 埼玉県北足立郡吹上町前砂160-1） Sanyo Electric Co., Ltd (160-1, Maesuna, Fukiagemachi, Kitaadachi-gun, Saitama 369-01)

***芝浦工業大学（干108 東京都港区芝浦3-9-14）

Shibaura Inst. of Tech. (9-14, Shibaura 3-chome, Minato-ku, Tokyo 108)

\section{3. 結果およひ考察}

\section{1 得られた皮膜の解析}

膜厚は, No. 1, 4 が $2 \sim 3 \mu \mathrm{m}$, No. 2, 3 が $1 \mu \mathrm{m}$ 前 後であった。膜の表面は比較的平坦で, 断面は, No. 1 が 明確な柱状組織, No. 4 がTiC-TiNの二重構造を示して いるのに対し，No.2，3 は組織のはっきりしないち密な 膜であった。また，EPMAによる定量やX線回折の結 果, TiN膜は(111)の配向が強く, 化学量論比に近い組 成（N/Ti原子比 $=0.75 ）$ を持つ膜であることが分かっ た。

\section{2 耐孔食性}

図 1 に $30^{\circ} \mathrm{C}, 3 \% \mathrm{NaCl}$ 水溶液中でのアノード分極曲 線を示す。Tiアンダーコートした試料は, 未処理材に 比べ孔食発生電位が貴となり，耐孔食性が改善された。 一方, TiNのみの№.1 は, 未処理材とほとんど変わらず, バラッキによっては悪い場合ああった。

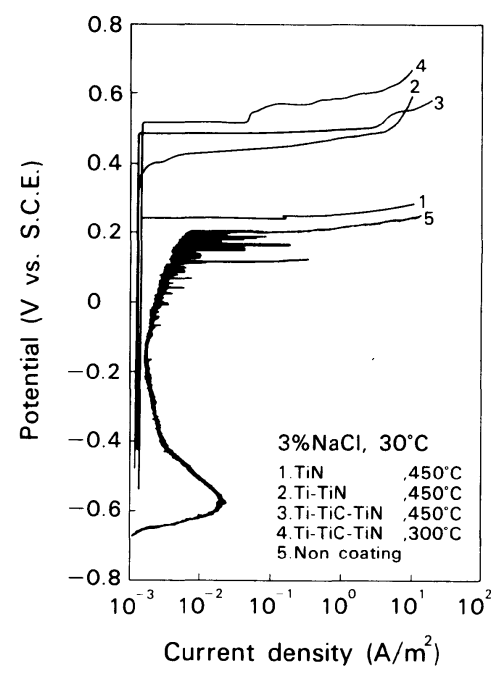

Fig. 1 Anodic polarization curves in $3 \% \mathrm{NaCl}$ at $30^{\circ} \mathrm{C}$. 


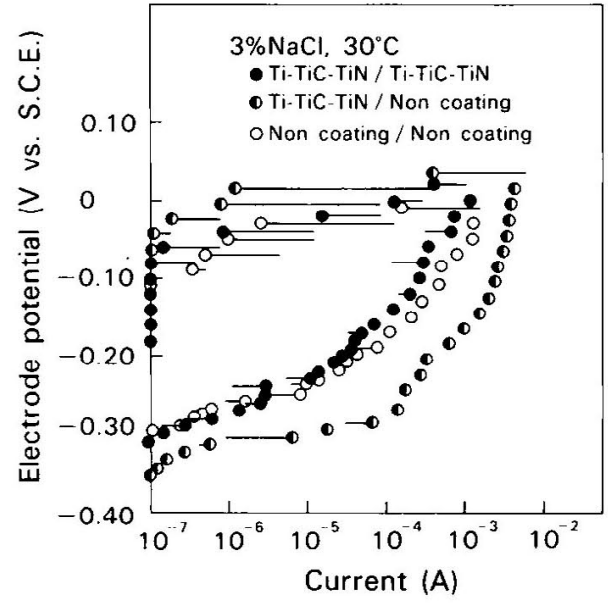

Fig. 2 Cyclic polarization curves in $3 \% \mathrm{NaCl}$ at $30^{\circ} \mathrm{C}$.

$E_{\text {corr }}$ の経時変化にも, Tiアンダーコートの有無により 顕著な差が認められ，No 1 は活性態域にとどまるのに対 し, NNo 2 4 は，周期的に不動態域と活性態域の間を变 動する傾向を示した。

また, $40^{\circ} \mathrm{C}, 0.1 \% \mathrm{NaCl}$ 水溶液, 1 週間の自然浸せ きによる重量減少量は，処理材（特にTiNのみ）の方か， 未処理材よりも多かった。これは，重量減少量がはく離 したTiN膜の重量を含んでいることにも原因があるが， 一旦孔食が発生すると，その後の孔食の進行は，TiN皮 膜によって電気化学的に促進されることを示唆している。

\section{3 耐すきま腐食性}

図 2 に $30^{\circ} \mathrm{C}, 3 \% \mathrm{NaCl}$ 水溶液中にて, 処理材どうし, 処理材と末処理材, 未処理材どうしの組み合わせで, $E_{\mathrm{R}}$ を測定した場合の絽り返し分極曲線を示す。処理材を含 む組み合わせは，未処理材のみに比べてすきま腐食開始 電位の値が貴となり， $E_{\mathrm{R}}$ の值が卑となった。すなわち， 未処理材に比べて腐食は起こりにくいが, 一旦起こると 再不動態化はしにくいということが分かった。

また， $40^{\circ} \mathrm{C} ， 3 \% \mathrm{NaCl}$ 水溶液， 1 ケ月間の自然浸せ きによる重量減少量は, TiNのみの組み合わせの場合, TiNのはく離のために著しく多くなったが，Tiアンダー コートした試料は，皮膜のはく離がほとんど認められず， 末処理材どうしよりあ少なくなった。なお，TiN処理に よって, 活性態域でのカソード反応が抑制されるが，こ れは，耐すきま腐食性の改善と関連があるすのと考えら れる。

\section{4 腐食形態}

図 3 に示したように，孔食電位測定後の腐食形態は， TiN のみの試料は，広く浅く腐食しており，母材に， 特有の波状か認められ，母材が浸食される前に次々と膜 がはがれ落ちていったものと推定される。一方，Ti ンダーコートした試料は，腐食孔があまり広がらず，母

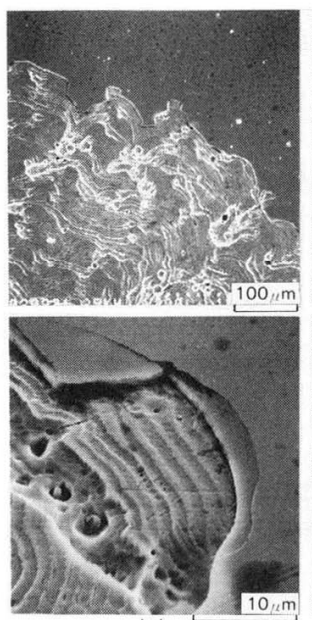

(a)

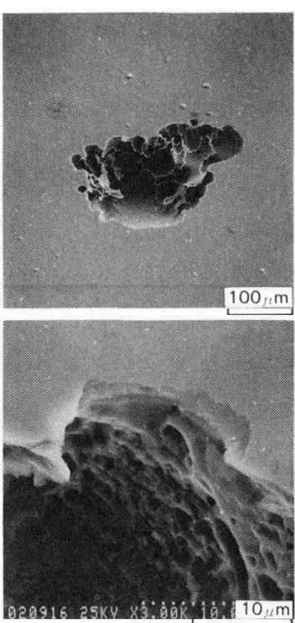

(b)
Fig. 3 Corrosion morphology after the anodic polarization in $3 \% \mathrm{NaCl}$ at $30^{\circ} \mathrm{C}$.

(a) $\mathrm{TiN}, 450{ }^{\circ} \mathrm{C} \quad$ (b) $\mathrm{Ti}-\mathrm{TiN}, 450{ }^{\circ} \mathrm{C}$

材部が深く浸食されていた。

また，膜の破面は，機械的に破壊した場合には，ほぼ 垂值に割れるのに対し，腐食によって破壊された場合は， 斜めに割れた部分が認められるなど，割れ形態に明瞭な 差があり，TiN膜自体も，母材等の腐食反応により影響 を受けているあのと推定される。

\section{4. 結言}

(1)今回，HCD式の工業炉によって得られたTiN皮膜は， 柱状組織で(111) 配向が強く, 化学量論比に近い膜であっ た。

(2)TiN処理することにより，孔食発生電位，すきま腐食 発生電位は貴となり，耐食性が问上するが，一旦腐食が 始まった場合には，再不動態化しにくく，腐食が進行し やすい傾向を持っことが分かった。

(3)'TiC積層や皮膜形成温度による差が少なく，Tiアンダー コートの有無による差が顕著であった。Tiアンダーコー トすることにより，機械的な密着性だけではなく，耐孔 食性, 耐すきま腐食性も向上し, 腐食形態にも差が認め られた。

終わりに，本研究を遂行するにあたり，有益な御助言 を賜りました東京都立工業技術センター仁平宣弘氏，並 びに棚木敏幸氏に感謝の意を表します。

(1989-5-2 受理)

\section{文献}

1) 柏木邦宏; 金属表面技術, 30，233（1979）

2）仁平宣弘；プラズマを利用した表面処理技術，東京都立工 業技術センタ一編（1988）

3）岸松雄, 渡辺 昭, 下山良造; 金属表面技術，35，50 (1984)

4 ）高橋夏木；金属表面技術，34，16（1984） 